\title{
Bacteriological Studies on Pathogens in Egyptian Pigeons.
}

\author{
Hala S. Ibrahim \\ Serology Unit, Animal Health Research Institute, Dokki, Giza, Egypt.
}

\begin{abstract}
The prevalence rate of bacterial isolates of public health importance in pigeons was $(28.16 \%)$. The incidence of bacterial pathogens differed according to health status of examined pigeons and ages either squabs or adults, as it gave the higher incidence in freshly dead squabs $(33.33 \%)$ and in adults $(28.57 \%)$ followed by diseased squabs $(31.03 \%)$ and adults $(26.67 \%)$ then finally slaughtered pigeons $(25.56 \%)$. There was a wide range of bacterial pathogens isolated from nasal and cloacal swabs of diseased pigeons including $C$. jejuni, Citrobacter freundii, $D$. pneumoniae, $E$. coli, K. oxytoca, K. pneumoniae, Mannheimia haemolytica, P. aeruginosa, Salmonella spp, S. aureus and $Y$. enterocolitica. There were variations between the incidence and the species of pathogens isolated from cloacal and nasal swabs either in squabs or in adults $K$. oxytoca, Mannheimia haemolytica and $Y$. enterocolitica never isolated from adult. It was appeared that the deaths usually occurred due to combination of more than one bacterium. On the examination of internal organs slaughtered pigeons, there were differences in the incidences of bacterial isolation form different organs. Serological identification of most prevalent isolates revealed 5 Salmonella serovars including, $3 \mathrm{P}$. aeruginosa serogroups and $6 \mathrm{E}$. coli serogroups. All examined pathogens were sensitive to enrofloxacin followed by gentamicin then ciprofloxacin. In contrast, streptomycin then erythromycin and colistin sulphate showed the lowest effect. Among the isolates tested, $P$. aeruginos $a$ was resistant to the most used antibiotics..Most isolated strains of $E$. coli, $P$. aeruginosa, Salmonella spp. and $Y$. enterocolitica from pigeons were elaborating enterotoxin. $S$. paratyphi $A$ and $S$ typhimurium var. copenhagen were $100 \%$ enterotoxigenic followed by $S$. typhimurium $(83.33 \%)$, E. coli $\mathrm{O}_{8}$ and Ps. aeruginosa $I(75 \%)$ in each. On other hand, lower enterotoxin production was observed in Ps. aeruginosa $A(46.15 \%)$ and E. coli $O_{111}(44.44 \%)$.
\end{abstract}

Pigeons are widely distributed in Egypt and considered as an important bird for many people especially in fest, for hunting and racing, many farmers reared them in their houses and considered an essential food for rich people. Pigeons are potential reservoirs for several pathogenic microorganisms, their faeces and other body fluids may harbour several pathogenic bacteria, which contributed to contaminate ponds, lacks, parks, garden and soils. Tanaka et al., (2005) considered pigeons faeces as a source of several zoonotic agents for birds, animals and humans especially Salmonella, E. coli $\mathrm{O} 157$ as well as Mycobacterium spp. also pigeons considered as a possible reservoir of Shiga toxin producing E. coli pathogenic to human (Sonntag et al., 2005). Campylobacter jejuni was the most frequently isolated microorganism, found in pigeons (Casanovas et al., 1995). In human, these bacteria can cause gastroenteritis, respiratory symptoms, septicemia, and even mortality, also, they cause low production and mortalities in infected birds, as $S$. Typhimurium var. Copenhagen mostly causes intestinal problems, diarrhoea and can also penetrate the intestinal tract and cause internal and neurotic problems.

Uncontrolled use of antibiotics in medicine and animal husbandry over the course of decades has fostered the selection of resistant bacteria (Tomasz, 1994). The rise in multi-drug resistant pathogenic bacteria is of global concern, because it can lead to increase human and domestic animals health care costs and increased morbidity and mortality (Williams and Heymann, 1998). Zoonotic bacteria especially salmonellae were shown to survive and multiply in the dropping for up to one month after their deposition by pigeons and the dropping distributed over a large environmental conditions.Hence, the goal of this study was conducted to the following items.

Bacteriological examination of samples collected from Egyptian pigeons and complete identification of the pathogenic isolates of public health importace, serological identification of some pathogenic isolates and determination of antimicrobial susceptibility also insurance of the virulence of the most public health important pathogenic isolates by inoculation in 
experimentally laboratory animals (mice and chicks), finally detection of enterotoxigenic strains of some pathogenic isolates.

\section{Materials and methods}

Samples. A total of 778 samples were collected from 206 pigeons in different farmer houses, Giza zoo and poultry shops located throughout Egypt during the period from November, 2006 up to April, 2007. These samples were classified into groups as follows:

Diseased pigeons. The samples were collected from 58 squabs and 30 adult pigeons which showed signs of illness as nasal discharges, diarrhea (as green and watery droppings), dull and ruffled feathers. Samples included nasal and cloacal swabs from each bird.

Slaughtered and freshly dead pigeons. The samples were collected from 90 slaughtered and (21squabs and 7 adults) of freshly dead pigeons from either poultry shops or farmer houses. Samples included crops, pharyngeal swabs, lungs, livers, intestines and oviducts.Each sample was collected in sterile polyethylene plastic bag, while samples for Campylobacter examination were collected in sterile screw capped bottles containing transport broth with supplement. All samples were transferred in an icebox to the laboratory without delay.

\section{Bacteriological examination.}

Isolation and identification of Campylobacter. All samples in transport broth Campylobacter medium were cultured directly onto modified Campylobacter charcoal differential agar medium (C.C. D.A.) with supplement in duplicate. The inoculated plates were incubated at $37^{\circ} \mathrm{C}$ and $42^{\circ} \mathrm{C}$ for 72 hours in $10 \% \mathrm{CO}_{2}$ tension in anaerobic jar using gas generating kit. Motility test was done by using hanging drop technique to see the corkscrew like motion specific for Campylobacter and Gram s stain was also done to detect the characteristic comma shape of Campylobacter for all suspected colonies. The isolates were identified according to Koneman et al., (1997).

Isolation and identification of other bacteria. Each sample was cultured in peptone broth and incubated at $37^{\circ} \mathrm{C}$ for 24 hours then a loopfull was plated onto following solid media according to its specificity: Nutrient agar, 5\% sheep blood agar, MacConkey agar, DAS media, mannitol salt agar, S.S agar, medium contain cetrimid for $P$. aeruginosa and Yersinia selective agar with selective supplement. On the other hand, samples used for salmonellae examination were firstly incubated in Rappabort Vassiliadis at $42^{\circ} \mathrm{C}$ for
24 hours then plated onto S.S. agar. All inoculated plates were incubated aerobically at $37^{\circ} \mathrm{C}$ for $24-48$ hours. The colonies were identified and confirmed biochemically according to Koneman et al., (1997); Boone and Castenholz (2001); Quinn et al., (2002).

Serological identification of the most isolates. $E$. coli and $P$. aeruginosa isolates were serogrouped according to the procedure outline by Edwards and Ewing (1972); Homma (1982) respectively. Meanwhile, Salmonella isolates were serologically identified according to Kauffmann - White scheme as described by Kauffmann (1973). The typing antisera were obtained from Denka Seiken Co. Ltd, Tokyo, Japan using agglutination technique.

Antimicrobial susceptibility. This was done using disc diffusion standard technique according to Finegold and Martin (1982); Quinn et al., (2002) with Mueller Hinton medium, in Campylobacter investigation the medium was supplemented with 5\% sheep blood using the following (Oxoid) discs, cefadroxil $(30 \mu \mathrm{g})$, chloramphenicol $(30 \mu \mathrm{g})$, ciprofloxacin $(5 \mu \mathrm{g})$, colistin sulphate $(50 \mu \mathrm{g})$, doxycycline $(30 \mu \mathrm{g})$, enrofloxacin $(5 \mu \mathrm{g})$, erythromycin $(15 \mu \mathrm{g})$, flumequine $(30 \mu \mathrm{g}), \quad$ gentamicin $(10 \mu \mathrm{g})$, nitrofurantion $(300 \mu \mathrm{g})$, nalidixic acid $(30 \mu \mathrm{g})$ and streptomycin $(10 \mu \mathrm{g})$. the results were interpretated according to the manual supplied by Oxoid Company.

Pathogenicity test.

Mice (mouse lethality test). Two hundred \&sixty four (264) albino white mice with average weight of about 18-20 g and aged 28-30 days old were used to investigate the pathogenicity of various strains of 22 pathogens including $C$. jejuni, Citrobacter freundii, D. pneumoniae, E. coli serogroups (O8, O78, O86, O111, 0157 and O166) $K$. oxytoca, $K$. pneumoniae, Mannheimia haemolytica, $P$. aeruginosa A, P. aeruginosa $G, P$. aeruginosa I, S. Kentucky, S. Paratyphi A, S. Typhimurium, $S$. Typhimurium var. Copenhagen, S. Virgina, S. aureus and $Y$. enterocolitica. All mice were examined bacteriologically to ensure their freedom from pathogens. The mice were divided into groups each of 3 mice and inoculated I.P. with $0.1 \mathrm{ml}$ of $5 \times 10^{8} \mathrm{C}$. F. U/ mouse of the tested strain and kept separately, last group was kept as control and injected only with saline. Mice were kept under observation for 7-10 days, the numbers of dead mice were recorded and reisolation of inoculated strains was done.

Chick. Chicks of 3 days old obtained from El- 
Table (1): Prevalence rate of bacterial isolates of public health importance in pigeons.

\begin{tabular}{|c|c|c|c|c|}
\hline \multirow{2}{*}{$\begin{array}{c}\text { Health status of examined } \\
\text { pigeons }\end{array}$} & \multirow[t]{2}{*}{ Age } & \multirow[t]{2}{*}{$\begin{array}{l}\text { No. of examined } \\
\text { pigeons }\end{array}$} & \multicolumn{2}{|c|}{$\begin{array}{c}\text { Bacteriologically } \\
\text { Positive }\end{array}$} \\
\hline & & & No. & $\% *$ \\
\hline \multirow{2}{*}{ Freshly dead } & Squabs & 21 & 7 & 33.33 \\
\hline & Adults & 7 & 2 & 28.57 \\
\hline \multirow{2}{*}{ Diseased } & Squabs & 58 & 18 & 31.03 \\
\hline & Adults & 30 & 8 & 26.67 \\
\hline Slaughtered & Adults & 90 & 23 & 25.56 \\
\hline Total & & 206 & 58 & $* * 28.16$ \\
\hline
\end{tabular}

*The percentage was calculated according to the number of each type of examined pigeons.

**The percentage was calculated according to the total number of examined pigeons.

Wadi Company. Ten chicks were randomly taken and subjected to clinical, postmortem and bacteriological examination, which proved to be apparently healthy. All chicks were examined bacteriologically to exclude any bacterial pathogens. Four hundred \&forty four (440) chicks were divided into equal groups containing 5 chicks in each. Chicks of each group were individually infected per os with $0.5 \mathrm{ml}$ containing ( $5 \times 10^{8}$ C.F.U.) of the tested strain, last group was kept as control and injected only with saline. Chicks of all groups were kept under observation for 12 days, clinical signs and mortalities were recorded and postmortem and bacteriological examination were done to dead bird .The study was terminated at 12 days post infection and re-isolation of infected strain was done.

Infant mouse assay. Detection of heat stable enterotoxin by Robins-Brown et al., (1993). Preparation of culture filtrate via inoculation of each isolate in tryptone soya broth and incubated over night at $37^{\circ} \mathrm{C}$. Then $10 \mathrm{ml}$ of culture was placed in $200 \mathrm{ml}$ of medium containing $2 \%$ casamino acid, $1 \%$ yeast extract and $0.4 \%$ glucose $\mathrm{pH}(8.5)$ in $250 \mathrm{ml}$ flask. The inoculated flasks were incubated on a rotatory shaker 200 rpm at $37^{\circ} \mathrm{C}$ for 18 hours then centrifuged at $12000 \mathrm{x} g$ for 10 minutes. The supernatant was filtrated through Millipore membrane filter pore $0.45 \mu \mathrm{m}$ and stored at $-20^{\circ} \mathrm{C}$ until used. A part of sterile medium was used as control. Infant mouse assay $0.1 \mathrm{ml}$ of each filtrate was injected through the abdominal wall into milk filled stomach of each 3 mice 2-4 days old for each examined strain and 3 infant mice were injected by $0.1 \mathrm{ml}$ of sterile medium and were used as negative control. After 4 hours, the mice were killed and the entire intestine was removed. The intestine and remaining body were weight to calculate the ratio of intestine weight/remaining body weight. Ratio greater than (0.083) was recorded as positive test for enterotoxin.

\section{Results and Discussion}

Pigeons are free-living birds so spreads of infectious agents occur through faecal contamination of drinking water sources, pastures and agricultural crops and may also come into close contact with domestic birds enabling direct transfer of infectious agents to take place, especially when they are kept out of doors. In general the prevalence rate of bacterial isolates of public health importance in pigeons was $(28.16 \%)$, this incidence may be indicated that pigeons mainly affected by viral and parasitic causes other than bacterial one. The incidence of bacterial pathogens differed according to health status of examined pigeons and age either squabs or adults, as it gave the higher incidence in freshly dead squabs (33.33\%) and in adults $(28.57 \%)$ followed by diseased squabs (31.03\%) and adults (26.67\%) then finally slaughtered pigeons $(25.56 \%)$. This may be attributed to the location of samples collection, husbandry, farmer management and kind of feed and finally to grassing area, as represented in table (1). It was clear that incidence of bacterial pathogens in squabs was higher than adults which may be due to lower immunity in young.

The data achieved in table (2) showed that there was a wide range of bacterial pathogens isolated from nasal and cloacal swabs of diseased pigeons including C. jejuni, Citrobacter freundii, D. pneumoniae, E. coli, K. oxytoca, K. pneumoniae, Mannheimia haemolytica, P. aeruginosa, Salmonella spp, S. aureus and Y. enterocolitica. There were variations between the incidence and the species of pathogens isolated from cloacal and nasal swabs either in squabs or in adults. K. oxytoca, Mannheimia haemolytica and $Y$. enterocolitica never isolated from adults. 
Table (2): Prevalence rate of bacterial pathogens of public health importance isolated from diseased pigeons.

\begin{tabular}{|c|c|c|c|c|c|c|c|c|}
\hline \multirow{3}{*}{ Type of swabs } & \multicolumn{4}{|c|}{ Nasal } & \multicolumn{4}{|c|}{ Cloacal } \\
\hline & \multicolumn{2}{|c|}{ Squabs (58) } & \multicolumn{2}{|c|}{ Adults (30) } & \multicolumn{2}{|c|}{ Squabs (58) } & \multicolumn{2}{|c|}{ Adults (30) } \\
\hline & No. & $\% *$ & No. & $\% * *$ & No. & $\% *$ & No. & $\% * *$ \\
\hline C. jejuni & 0 & 0 & 0 & 0 & 4 & 6.70 & 2 & 6.66 \\
\hline Citrobacter freundii & 0 & 0 & 0 & 0 & 2 & 3.45 & 1 & 3.33 \\
\hline D. pneumoniae & 3 & 5.17 & 1 & 3.33 & 0 & 0 & 0 & 0 \\
\hline E. coli & 3 & 5.17 & 1 & 3.33 & 5 & 8.62 & 3 & 10.00 \\
\hline K. oxytoca & 0 & 0 & 0 & 0 & 1 & 1.72 & 0 & 0 \\
\hline K. pneumoniae & 3 & 5.17 & 1 & 3.33 & 0 & 0 & 0 & 0 \\
\hline Mannheimia haemolytica & 1 & 1.72 & 0 & 0 & 0 & 0 & 0 & 0 \\
\hline P. aeruginosa & 2 & 3.45 & 1 & 3.33 & 2 & 3.45 & 1 & 3.33 \\
\hline Salmonella spp & 0 & 0 & 0 & 0 & 3 & 5.17 & 1 & 3.33 \\
\hline S. aureus & 3 & 5.17 & 2 & 6.66 & 0 & 0 & 0 & 0 \\
\hline Y. enterocolitica & 0 & 0 & 0 & 0 & 1 & 1.72 & 0 & 0 \\
\hline
\end{tabular}

*The percentage was calculated according to the total number of examined diseased squabs (58).

**The percentage was calculated according to the total number of examined diseased adult pigeons (30).

In this concern, Casanovas et al., (1995) recorded that $C$. jejuni was the most isolates found in 105 pigeons $(26.2 \%)$ then Salmonella spp. were isolated from six specimens $(1.5 \%)$ and Yersinia spp. was isolated from only one pigeon in the city of Barcelona. In addition, Adesiyun et al., (1998) mentioned that (5\%) of racing pigeons that originated from 8 fanciers in Trinidad yielded Salmonella spp. all of which were $S$. Typhimurium while only (1\%) was positive for Campylobacter spp. Otherwise, Methner and Lauterbach (2003) isolated Salmonella in an incidence of (7.04\%) from faecal samples in purebred pigeons. While, Dovc et al., (2004) recorded that Salmonella spp. were isolated from $(5.7 \%)$ of the cloacal swabs of free-living pigeons in the city of Ljubljana, Slovenia. Otherwise, Pasmans et al., (2004) isolated $(22.8 \%)$ of $S$. Typhimurium var. Copenhagen from pooled faecal samples from pigeon lofts from the city of Ghent (Belgium). Furthermore, Sonntag et al., (2005) considered the pigeons as a possible reservoir of Shiga toxin 2f-producing $E$. coli associated with human disease. Meanwhile, Lillehaug et al., (2005) detected Campylobacter jejuni in fresh faecal samples of six out of 200 feral pigeons while all samples were negative for salmonellae. In addition, Tanaka et al., (2005) isolated salmonellae from $(3.9 \%)$ of faecal samples from feral pigeons in Japan. McCrea et al., (2006) isolated Campylobacter and Salmonella spp. from live bird to prepackaged carcass for 3 flocks of squab. Pedersen et al., (2006) detected $S$. enterica in an incidence of (3.2\%) from pigeons captured in Fort Collins, Colorado.

Concerning the results in tables (3-4) C. jejuni, Citrobacter freundii, D. pneumoniae, $E$. coli, K. oxytoca, K. pneumoniae, Mannheimia haemolytica, P. aeruginosa, Salmonella spp, S. aureus and $Y$. enterocolitica were isolated from freshly dead squabs. While in 2 freshly dead adult pigeons C. jejuni, E. coli, Salmonella spp, and $S$. aureus were isolated. From this data, it was appeared that the deaths usually occurred due to combination of more than one bacterium. The prevalence rate of $E$. coli was very high, this may be attributed to the fact that $E$. coli overgrows the normal intestinal flora and could produce toxins that could reach the blood and caused intoxication, so young pigeons become sick and died. In addition, $S$. Typhimurium could penetrate the intestinal tract and caused internal and neurotic problems in addition to deaths. The result proved that these pathogens not only constitute public hazard for human beings but also cause deaths of birds. It is very important to get rid of dead pigeons in good hygienic measures to prevent spread of pathogenic organisms to human and other livestocks and avoid contamination of environment. This data agree with those reported by Pennycott et al., (2005) who recovered S. Typhimurium from 8 carcasses and E. coli $\mathrm{O} 86$ from 3 carcasses found in dead birds in south-west Scotland. 
Table (3): Prevalence rate of bacterial pathogens of public health importance isolated from freshly dead squabs.

\begin{tabular}{|c|c|c|c|c|c|c|c|c|c|c|}
\hline \multirow[t]{2}{*}{ Isolated pathogens } & \multicolumn{2}{|c|}{ Crops } & \multicolumn{2}{|c|}{$\begin{array}{c}\text { Pharyngeal } \\
\text { swabs } \\
\end{array}$} & \multicolumn{2}{|c|}{ Lungs } & \multicolumn{2}{|c|}{ Livers } & \multicolumn{2}{|c|}{ Intestines } \\
\hline & No. & $\%$ & No. & $\%$ & No. & $\%$ & No. & $\%$ & No. & $\%$ \\
\hline C. jejuni & 1 & 4.76 & 0 & 0 & 0 & 0 & 2 & 9.52 & 3 & 14.29 \\
\hline Citrobacter freundii & 1 & 4.76 & 0 & 0 & 0 & 0 & 1 & 4.76 & 1 & 4.76 \\
\hline D. pneumoniae & 0 & 0 & 1 & 4.76 & 2 & 9.52 & 1 & 4.76 & 0 & 0 \\
\hline E. coli & 2 & 9.52 & 2 & 9.52 & 3 & 14.29 & 4 & 19.05 & 5 & 23.81 \\
\hline K. oxytoca & 0 & 0 & 0 & 0 & 0 & 0 & 1 & 4.76 & 1 & 4.76 \\
\hline K. pneumoniae & 0 & 0 & 1 & 4.76 & 1 & 4.76 & 1 & 4.76 & 0 & 0 \\
\hline Mannheimia haemolytica & 0 & 0 & 0 & 0 & 2 & 9.52 & 1 & 4.76 & 0 & 0 \\
\hline P. aeruginosa & 1 & 4.76 & 1 & 4.76 & 1 & 4.76 & 2 & 9.52 & 2 & 9.52 \\
\hline Salmonella spp & 1 & 4.76 & 0 & 0 & 0 & 0 & 2 & 9.52 & 4 & 19.05 \\
\hline S. aureus & 0 & 0 & 1 & 4.76 & 3 & 14.29 & 1 & 4.76 & 0 & 0 \\
\hline Y. enterocolitica & 0 & 0 & 0 & 0 & 0 & 0 & 1 & 4.76 & 1 & 4.76 \\
\hline
\end{tabular}

The percentage was calculated according to the total number of examined freshly dead squabs (21).

Table (4): Prevalence rate of bacterial pathogens of public health importance isolated from freshly dead adult pigeons.

\begin{tabular}{lcccccccccc}
\hline $\begin{array}{l}\text { Isolated } \\
\text { pathogens }\end{array}$ & \multicolumn{2}{c}{ Crops } & \multicolumn{3}{c}{$\begin{array}{c}\text { Pharyngeal } \\
\text { swabs }\end{array}$} & \multicolumn{2}{c}{ Lungs } & \multicolumn{2}{c}{ Livers } & \multicolumn{2}{c}{ Intestines } \\
\cline { 2 - 11 } & No. & $\%$ & No. & $\%$ & No. & \% & No. & \% & No. & \% \\
\hline C. jejuni & 1 & 14.29 & 0 & 0 & 0 & 0 & 1 & 14.29 & 1 & 14.29 \\
E. coli & 1 & 14.29 & 1 & 14.29 & 1 & 14.29 & 2 & 28.57 & 2 & 28.57 \\
Salmonella spp & 0 & 0 & 0 & 0 & 0 & 0 & 2 & 28.57 & 2 & 28.57 \\
S. aureus & 0 & 0 & 1 & 14.29 & 1 & 14.29 & 1 & 4.76 & 0 & 0 \\
\hline
\end{tabular}

The percentage was calculated according to the total number of examined freshly dead adult pigeons (7).

On the examination of internal organs including crops, pharyngeal swabs, livers, intestines and lungs of slaughtered pigeons, it was clear that there were differences in the incidences and organs from which the following pathogens $C$. jejuni, D. pneumoniae, E. coli, $K$. oxytoca, $K$. pneumoniae, Mannheimia haemolytica, $P$. aeruginosa, Salmonella spp, $S$. aureus and $Y$. enterocolitica were isolated as achieved in table (5). Many investigators concerned with bacteria isolated from slaughtered pigeons as Jeffrey et al., (2001) on microbiological testing for Campylobacter and Salmonella in squabs processing plant in three separate trials, found that the overall prevalence of positive samples in trial (1) was (1.4\%) for Salmonella spp. and (11.1\%) for C. jejuni in trial (2) (4.3 and 0\%) for Salmonella spp. and $C$. jejuni and in trial (3) (4.1 and 4.8\%) for Salmonella spp. and $C$. jejuni respectively. Otherwise, Pasmans et al., (2004) isolated (3.3\%) S. Typhimurium var. Copenhagen from pooled samples of livers, intestines and spleens of feral pigeons from the city of Ghent
(Belgium). Furthermore, Losito et al., (2005) isolated Staphylococcal strains from a pigeon slaughterhouse in central Italy.

Otherwise, Soncini et al., (2006) isolated Campylobacter from (15.8\%) of pigeon s neck skin, $(12.5 \%)$ of pigeon $\mathrm{s}$ meat samples. The isolation of these pathogens from slaughtered pigeons may be attributed to their illness before slaughtering or contamination during slaughtering due to bad hygienic measures, using of contaminated utensils or surface contamination during evisceration of the birds from rupture of intestinal tract or occur via infected human during handling of raw pigeons.

The presences of the pathogens in oviduct were very important as it may disseminate these pathogens to eggs causing economic losses and causing zoonotic diseases to consumers. E. coli, P. aeruginosa and Salmonella spp. were isolated from oviducts of examined slaughtered pigeons. Meanwhile only E. coli and Salmonella spp. were isolated from oviducts of examined dead pigeons, as demonstrated in table(6). 
Table (5): Prevalence rate of bacterial pathogens of public health importance isolated from slaughtered pigeons.

\begin{tabular}{|c|c|c|c|c|c|c|c|c|c|c|}
\hline \multirow[t]{2}{*}{ Isolated pathogens } & \multicolumn{2}{|c|}{ Crops } & \multicolumn{2}{|c|}{$\begin{array}{c}\text { Pharyngeal } \\
\text { swabs } \\
\end{array}$} & \multicolumn{2}{|c|}{ Lungs } & \multicolumn{2}{|c|}{ Livers } & \multicolumn{2}{|c|}{ Intestines } \\
\hline & No. & $\%$ & No. & $\%$ & No. & $\%$ & No. & $\%$ & No. & $\%$ \\
\hline C. jejuni & 2 & 2.22 & 0 & 0 & 0 & 0 & 5 & 5.56 & 8 & 8.89 \\
\hline D. pneumoniae & 0 & 0 & 2 & 2.22 & 7 & 7.78 & 4 & 4.44 & 0 & 0 \\
\hline E. coli & 4 & 4.44 & 6 & 6.66 & 5 & 5.56 & 6 & 6.67 & 8 & 8.89 \\
\hline K. oxytoca & 2 & 2.22 & 2 & 2.22 & 0 & 0 & 2 & 2.22 & 5 & 5.56 \\
\hline K. pneumoniae & 0 & 0 & 2 & 2.22 & 4 & 4.44 & 3 & 3.33 & 0 & 0 \\
\hline Mannheimia haemolytica & 0 & 0 & 1 & 1.11 & 3 & 3.33 & 2 & 2.22 & 0 & 0 \\
\hline$P$. aeruginosa & 1 & 1.11 & 2 & 2.22 & 3 & 3.33 & 2 & 2.22 & 3 & 3.33 \\
\hline Salmonella spp & 2 & 2.22 & 0 & 0 & 0 & 0 & 3 & 3.33 & 4 & 4.44 \\
\hline S. aureus & 0 & 0 & 5 & 5.56 & 8 & 8.89 & 6 & 6.67 & 0 & 0 \\
\hline Y. enterocolitica & 1 & 1.11 & 0 & 0 & 0 & 0 & 2 & 2.22 & 3 & 3.33 \\
\hline
\end{tabular}

The percentage was calculated according to the total number of examined slaughtered pigeons. (90).

Table (6): Prevalence rate of bacterial pathogens of public health importance isolated from oviducts of examined pigeons.

\begin{tabular}{lccccc}
\hline & Type & \multicolumn{2}{c}{ Slaughtered $(\mathbf{n}=\mathbf{1 0})$} & \multicolumn{2}{c}{ Dead $(\mathbf{n}=\mathbf{2})$} \\
\cline { 3 - 6 } Isolated Pathogens & No. & \% & No. & $\%$ \\
\hline E. coli & 5 & 50 & 2 & 100 \\
P. aeruginosa & 1 & 10 & 0 & 0 \\
Salmonella spp. & 2 & 20 & 1 & 50 \\
\hline
\end{tabular}

The percentage was calculated according to the number of each type of tested pigeons.

Table (7) Serological identification of most prevalent isolates.

\begin{tabular}{|c|c|c|c|c|c|c|c|c|}
\hline \multirow[b]{2}{*}{ Serovars } & lla se & ars & \multicolumn{3}{|c|}{ P. aeruginosa } & \multicolumn{3}{|c|}{ E. coli } \\
\hline & NO. & $\%$ & Serogroups & NO. & $\%$ & Serogroups & NO. & $\%$ \\
\hline S. kentucky & 3 & 11.11 & $\mathrm{~A}$ & 11 & 44 & $\mathrm{O} 8$ & 12 & 16.90 \\
\hline S. paratyphi $A$ & 3 & 11.11 & $\mathrm{G}$ & 7 & 28 & $\mathrm{O} 78$ & 15 & 21.13 \\
\hline S. typhimurium & 12 & 44.44 & I & 4 & 16 & O86 & 13 & 18.31 \\
\hline $\begin{array}{l}\text { S. typhimurium var. } \\
\text { Copenhagen }\end{array}$ & 7 & 25.93 & Untyped & 3 & 12 & 0111 & 9 & 12.68 \\
\hline S. virgina & 2 & 7.41 & & & & $\begin{array}{l}\text { O157 } \\
\text { O166 }\end{array}$ & $\begin{array}{c}7 \\
13\end{array}$ & $\begin{array}{c}9.86 \\
18.31\end{array}$ \\
\hline & & & & & & Untyped & 2 & 2.81 \\
\hline Total & 27 & 100 & & 25 & 100 & & 71 & 100 \\
\hline
\end{tabular}

N.B. Number of isolate was from all examined samples even in the same bird and the percentage was calculated according to the total number of each isolate.

The results presented in table (7) revealed 5 Salmonella serovars including $S$. kentucky, $S$. paratyphi A, S. typhimurium, S. typhimurium var Copenhagen and $S$. virgina. On identification of $P$. aeruginosa isolates serogroups $\mathrm{A}, \mathrm{G}$ and $\mathrm{I}$ were identified. On the other hands, E. coli isolates were serogrouped as $\mathrm{O} 8, \mathrm{O} 78, \mathrm{O} 86$, O111, O157 and O166. These results were partially agree with that reported by Methner and Lauterbach (2003) who found that all
Salmonella isolated from faecal samples in purebred pigeons belonged to the serovar Typhimurium var. Copenhagen. In addition, Tanaka et al., (2005) isolated S. typhimurium and $S$. cerro from feral pigeons in Japan. Meanwhile, similar results were reported by Pasmans et al., (2004) who isolated (22.8\%) of $S$. typhimurium var. Copenhagen from pooled faecal samples from pigeon lofts from the city of Ghent (Belgium). 
The antimicrobial susceptibility of many strains of 22 pathogens isolated from pigeons revealed variable results in susceptibilities and zones of inhibition to different chemotherapeutic agents and antibiotics, all examined pathogens were sensitive to enrofloxacin, followed by gentamicin then ciprofloxacin. In contrast to streptomycin then erythromycin and colistin sulphate showed the lowest effect. Among the isolates tested, $P$. aeruginosa was resistant to the most used antibiotics, as illustrated in table (8). In general, there were good susceptibilities to many examined agents these might due to fact that pigeon not take antibiotic continuously as other animals. In this aspect Kimpe et al., (2002) on examination of antimicrobial susceptibility of 60 E. coli and $18 \mathrm{~S}$. Typhimurium var. Copenhagen strains isolated from homing pigeons, found that E. coli strains was resistant to all antibiotics tested. Over one-half of them were resistant to tetracycline, penicillins, and ampicillin, however, none showed extended spectrum beta-lactamase activity, implying that the cephalosporins remained active. Resistance to trimethoprim, aminoglycosides and fluoroquinolone ranked next. In contrast to the E. coli strains, the $S$. enterica strains were susceptible to all the antimicrobials tested. Also, Seepersadsingh and Adesiyun (2003) recorded that the highest prevalence of resistance was $(83.3 \%)$ to streptomycin among salmonella isolates from birds. Meanwhile, Losito et al., (2005) mentioned that $S$. aureus isolated from pigeon slaughterhouses in central Italy were sensitive to amoxicillin/clavulanic acid, cephalothin, gentamicin, kanamycin, oxacillin, rifampicin, tobramycin, trimethoprimsulfamethoxazole, vancomycin. Some (15.2\%) of the strains were resistant to ampicillin and to penicillin G; $(6.8 \%)$ were resistant to chloramphenicol, $(20.3 \%)$ to enrofloxacin, $(16.9 \%)$ to erythromycin and to ciprofloxacin, $(8.5 \%)$ to clindamycin, and $(11.9 \%)$ to lincomycin. The highest percentages of strains were resistant to tetracycline $(37.3 \%)$. Only one strain had a multiple antibiotic resistance.

The results achieved in tables (9-10) showed the virulence of different pathogens as demonstrated by the sequence of mortality of mice injected with test pathogens separately I/P. It was clear that D. pneumoniae, E. coli O157, Mannheimia haemolytica, P. aeruginosa I, S. paratyphi A and $S$. typhimurium var. Copenhagen were highly virulent strains for mice followed by E. coli $\mathrm{O} 78$ and $P$. aeruginosa $G$. On the other hand, $K$. oxytoca and Y. enterocolitica then C. jejuni were lower in their virulence. In addition, showed the pathogenicity of the same pathogens in chicks it was appeared that there were great variations in morbidity and mortality rates and case fetality rate with different examined isolates. P. aeruginosa I showed $(100 \%)$ mortality and case fetality rate then $(90 \%)$ of $S$. typhimurium var. Copenhagen. Meanwhile, K. oxytoca and S. kentucky gave $(0 \%)$. These variations in the data of pathogenicity tests may be attributed to pathogenic nature of the examined strains or the presence of virulence associated plasmid or production of endo or exotoxins and finally type of used laboratory animals. Similar result was reported by Helm et al., (2004) who found that S. typhimurium frequently associated with pigeon infections were still virulent in mice. Otherwise, Pasmans et al., (2004) recorded that $S$. typhimurium var. Copenhagen strains isolated from feral pigeons were the high virulence for mice. The present investigation achieved in table (11) shows that the most isolated strains of E. coli, $P$. aeruginosa, Salmonella spp. and $Y$. enterocolitica from pigeons were elaborating enterotoxin. S.paratyphi A and $S$ typhimurium var. Copenhagen were $(100 \%)$ enterotoxigenic followed by $S$. typhimurium $(83.33 \%), E$. coli $\mathrm{O} 8$ and $P$. aeruginosa I (75\%) in each. On other hand, lower enterotoxin production was observed in $P$. aeruginosa A $(46.15 \%)$ and E. coli $\mathrm{O} 111$ $(44.44 \%)$. It could be concluded that there is a potentially high risk of human exposure to excreta of pigeons that may serve as reservoirs for many zoonotic pathogens, so that live pigeons must be subjected to periodical examination. In addition, the importance of cleaning and sanitation programs and personal hygiene in farmer houses and poultry shops to avoid contamination and to get ride of dead pigeons in correct hygienic measures to avoid contamination of environment and spread of diseases to human and other live stocks.

\section{Reference}

Adesiyun, A.A.; Seepersadsingh, N.; Inder, L. and Caesar, K. (1998 ): Some bacterial enteropathogens in wildlife and racing pigeons from Trinidad. J Wild.1 .Dis., 34(1):73-80.

Boone, D.R. and Castenholz, R.W. (2001): "Bergey s manual of systemic bacteriology." Sec. Ed. Vol. (1): USA.

Casanovas, L.; de Simon, M.; Ferrer, M. D.; Arques, J. and Monzon, G. (1995): Intestinal carriage of campylobacters, salmonellas, yersinias and listerias in pigeons in the city of Barcelona. J Appl. Bacteriol., 78(1):1113.

Dovc, A.; Zorman-Rojs, O.; Vergles Rataj, A.; BoleHribovsek, V.; Krapez, U. and Dobeic, M. (2004): Health status of free-living pigeons (Columba livia 
Table (8) Antimicrobial susceptibility of the most common bacterial isolates.

\begin{tabular}{|c|c|c|c|c|c|c|c|c|c|c|c|c|c|c|c|c|c|c|c|c|c|c|c|c|}
\hline \multirow[t]{2}{*}{ Antibiot } & \multirow{3}{*}{\multicolumn{2}{|c|}{$\begin{array}{l}\mathbf{N} \\
\mathbf{0} \\
0\end{array}$}} & \multirow{2}{*}{\multicolumn{2}{|c|}{ 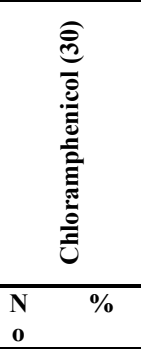 }} & \multirow[t]{2}{*}{$\begin{array}{c}\text { No } \\
\text { Non }\end{array}$} & \multirow[t]{2}{*}{$(6$} & \multirow[b]{2}{*}{0} & \multirow[t]{2}{*}{ 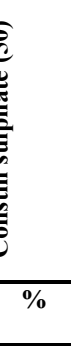 } & \multicolumn{2}{|c|}{ 莺 } & \multicolumn{2}{|c|}{ 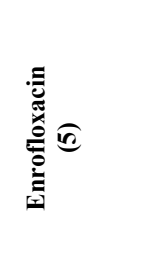 } & \multicolumn{2}{|c|}{ 氞 } & \multicolumn{2}{|c|}{  } & \multicolumn{2}{|c|}{ 总 } & \multicolumn{2}{|c|}{ 总 } & \multicolumn{2}{|c|}{  } & \multicolumn{2}{|c|}{ 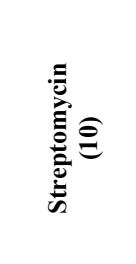 } \\
\hline & & & & & & & & & No & $\%$ & No & $\%$ & No & $\%$ & No & $\%$ & $\begin{array}{l}\mathbf{N} \\
\mathbf{0} \\
\end{array}$ & $\%$ & No & $\%$ & No & $\%$ & No & $\%$ \\
\hline C. jejuni 10 & & & 6 & 60 & 0 & $\overline{0}$ & 0 & 0 & 10 & 100 & 10 & 100 & 1 & 10 & 0 & 0 & 8 & 80 & 4 & 40 & 2 & 20 & 0 & 0 \\
\hline Citrobacter freundii 3 & 2 & 66.7 & 2 & 66.7 & 1 & 33.3 & 1 & 33.3 & 3 & 100 & 3 & 100 & 0 & 0 & 2 & 66.7 & 1 & 33.3 & 2 & 66.7 & 2 & 66.7 & 1 & 33.3 \\
\hline D. pneumoniae 7 & 6 & 85.7 & 5 & 71.4 & 2 & 28.6 & 0 & 0 & 5 & 71.4 & 7 & 100 & 0 & 0 & 0 & 0 & 1 & 14.3 & 0 & 0 & 0 & 0 & 1 & 14.3 \\
\hline E. coli O8 4 & 3 & 75 & 2 & 50 & 3 & 75 & 2 & 50 & 3 & 75 & 4 & 100 & 1 & 25 & 3 & 75 & 4 & 100 & 2 & 50 & 2 & 50 & 1 & 25 \\
\hline E. coli 0785 & 3 & 60 & 1 & 20 & 4 & 80 & 0 & 0 & 3 & 60 & 5 & 100 & 0 & 0 & 3 & 60 & 5 & 100 & 3 & 60 & 3 & 60 & 1 & 20 \\
\hline E. coli 0864 & 2 & 50 & 3 & 75 & 4 & 100 & 2 & 50 & 2 & 50 & 4 & 100 & 2 & 50 & 2 & 50 & 2 & 50 & 2 & 50 & 2 & 50 & 2 & 50 \\
\hline E. coli 01113 & 3 & 100 & 2 & 66.7 & 3 & 100 & 1 & 33.3 & 3 & 100 & 3 & 100 & 2 & 66.7 & 2 & 66.7 & 3 & 100 & 1 & 33.3 & 0 & 0 & 0 & 0 \\
\hline E. coli 01573 & 2 & 66.7 & 1 & 33.3 & 3 & 100 & 1 & 33.3 & 1 & 33.3 & 3 & 100 & 0 & 0 & 2 & 66.7 & 3 & 100 & 2 & 66.7 & 1 & 33.3 & 0 & 0 \\
\hline E. coli 01664 & 2 & 50 & 2 & 50 & 4 & 100 & 2 & 50 & 2 & 50 & 4 & 100 & 1 & 25 & 3 & 75 & 4 & 100 & 2 & 50 & 2 & 50 & 1 & 25 \\
\hline K. oxytoca 3 & 2 & 66.7 & 0 & 0 & 3 & 100 & 0 & 0 & 2 & 66.7 & 3 & 100 & 0 & 0 & 3 & 100 & 3 & 100 & 2 & 66.7 & 1 & 33.3 & 0 & 0 \\
\hline K. pneumoniae 5 & 4 & 80 & 0 & 0 & 4 & 80 & 0 & 0 & 3 & 60 & 5 & 100 & 0 & 0 & 3 & 60 & 5 & 100 & 4 & 80 & 2 & 40 & 0 & 0 \\
\hline $\begin{array}{l}\text { Mannheimia haemolytica } \\
3\end{array}$ & 0 & 0 & 0 & 0 & 1 & 33.3 & 0 & 0 & 3 & 100 & 2 & 66.7 & 0 & 0 & 0 & 0 & 2 & 66.7 & 0 & 0 & 0 & 0 & 0 & 0 \\
\hline P. aeruginosa A 4 & 0 & 0 & 0 & 0 & 0 & 0 & 0 & 0 & 0 & 0 & 4 & 100 & 0 & 0 & 0 & 0 & 4 & 100 & 0 & 0 & 0 & 0 & 2 & 50 \\
\hline P. aeruginosa G 3 & 0 & 0 & 0 & 0 & 0 & 0 & 0 & 0 & 0 & 0 & 3 & 100 & 0 & 0 & 0 & 0 & 3 & 100 & 0 & 0 & 0 & 0 & 1 & 33.3 \\
\hline P. aeruginosa I 2 & 0 & 0 & 0 & 0 & 0 & 0 & 0 & 0 & 0 & 0 & 2 & 100 & 0 & 0 & 0 & 0 & 2 & 100 & 0 & 0 & 0 & 0 & 1 & 50 \\
\hline S. Kentucky 2 & 0 & 0 & 1 & 50 & 2 & 100 & 2 & 100 & 0 & 0 & 2 & 100 & 0 & 0 & 0 & 0 & 1 & 50 & 0 & 0 & 0 & 0 & 0 & 0 \\
\hline S. Paratyphi A 2 & 2 & 100 & 2 & 100 & 2 & 100 & 1 & 50 & 2 & 100 & 2 & 100 & 0 & 0 & 2 & 100 & 1 & 50 & 0 & 0 & 0 & 0 & 0 & 0 \\
\hline S. Typhimurium 3 & 0 & 0 & 2 & 66.7 & 3 & 100 & 0 & 0 & 3 & 100 & 3 & 100 & 0 & 0 & 3 & 100 & 1 & 33.3 & 1 & 33.3 & 3 & 100 & 2 & 66.7 \\
\hline $\begin{array}{l}\text { S. Typhimurium var. } \\
\text { Copenhagen } 2\end{array}$ & 1 & 50 & 1 & 50 & 2 & 100 & 0 & 0 & 1 & 50 & 2 & 100 & 0 & 0 & 2 & 100 & 1 & 50 & 0 & 0 & 1 & 50 & 2 & 100 \\
\hline S. Virgina 2 & 0 & 0 & 2 & 100 & 2 & 100 & 1 & 50 & 0 & 0 & 2 & 100 & 0 & 0 & 0 & 0 & 1 & 50 & 0 & 0 & 1 & 50 & 0 & 0 \\
\hline S. aureus 10 & 6 & 60 & 8 & 80 & 8 & 80 & 0 & 0 & 7 & 70 & 10 & 100 & 5 & 50 & 8 & 80 & 10 & 100 & 9 & 90 & 4 & 40 & 5 & 50 \\
\hline Y. enterocolitica 3 & 2 & 66.7 & 3 & 100 & 1 & 33.3 & 0 & 0 & 3 & 100 & 3 & 100 & 2 & 66.7 & 2 & 66.7 & 3 & 100 & 1 & 33.3 & 3 & 100 & 1 & 33.3 \\
\hline
\end{tabular}

*Concent 'ration of used discs in $\boldsymbol{\mu g}$.

**No. and percentage of sensitive strains to examined chemotherapeutic \& antibiotic disc 
Table (9) Pathogenicity of the bacterial pathogens of public health importance isolated from pigeons in mice.

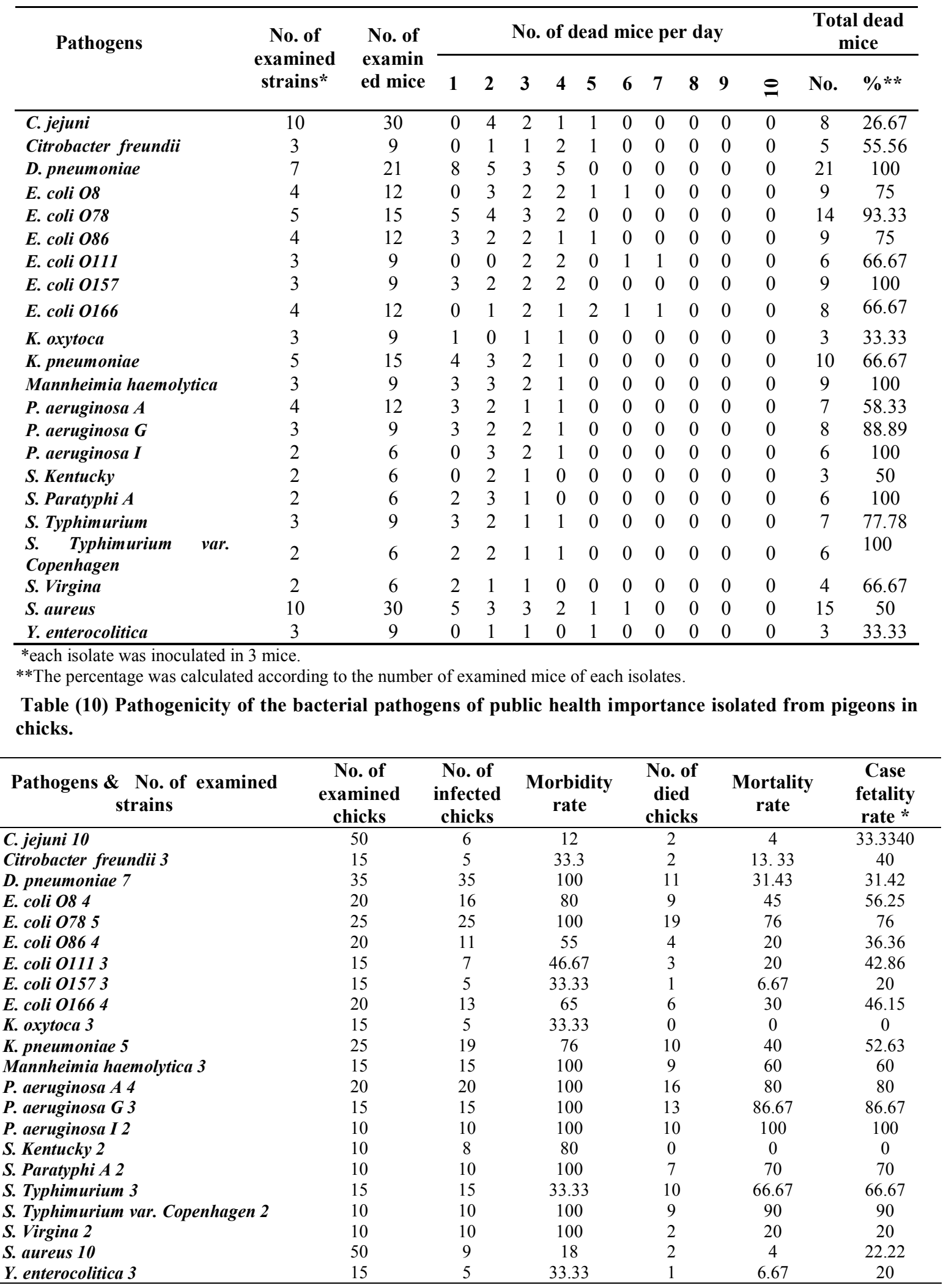

${ }^{*}$ Case fetality rate $=$ No. of died chicks $/$ No. of infected chicks. 
Table (11): Incidence of enterotoxigenic bacterial pathogens of public health importance isolated from pigeons.

\begin{tabular}{|c|c|c|c|c|c|c|c|c|c|c|c|c|c|c|c|c|}
\hline \multicolumn{2}{|c|}{ Pathogens } & $\begin{array}{l}\infty \\
0 \\
0 \\
0\end{array}$ & $\begin{array}{l}\infty \\
0 \\
0 \\
0 \\
0 \\
0\end{array}$ & $\begin{array}{l}0 \\
0 \\
0 \\
0 \\
0 \\
0\end{array}$ & 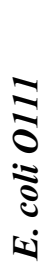 & 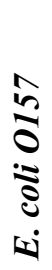 & $\begin{array}{l}0 \\
0 \\
0 \\
0 \\
0\end{array}$ & 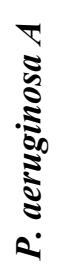 &  & 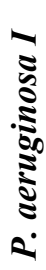 & ن & 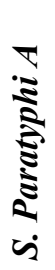 & ن &  & 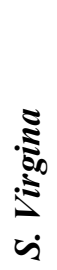 & 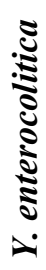 \\
\hline \multicolumn{2}{|c|}{$\begin{array}{c}\text { No. of } \\
\text { examined } \\
\text { strains }\end{array}$} & 12 & 15 & 13 & 9 & 7 & 13 & 11 & 7 & 4 & 3 & 3 & 12 & 7 & 2 & 9 \\
\hline  & $\dot{\mathbf{z}}$ & 9 & 10 & 8 & 4 & 4 & 6 & 7 & 5 & 3 & 2 & 3 & 10 & 7 & 1 & 6 \\
\hline 总 : & $\partial^{\circ}$ & $n$ & $\begin{array}{l}6 \\
0 \\
0\end{array}$ & $\stackrel{+}{n}$ & $\begin{array}{l}\dot{y} \\
\dot{f}\end{array}$ & $\frac{\nabla}{i}$ & $\stackrel{n}{\stackrel{n}{0}}$ & $\begin{array}{l}\text { オे } \\
\text { అु }\end{array}$ & $\stackrel{?}{\stackrel{P}{r}}$ & $n$ & $\begin{array}{l}\hat{\sigma} \\
\dot{0}\end{array}$ & 8 & $\stackrel{m}{\tilde{\infty}}$ & 8 & 요 & $\begin{array}{l}\hat{\sigma} \\
0 \\
0\end{array}$ \\
\hline
\end{tabular}

domestica) in the city of Ljubljana. Acta. Vet. Hung., 52(2):219-226.

Edwards, P.R. and Ewing, W. H. (1972): Identification of Enterobacteriaceae. 3rd Ed. Burgess publishing Co. Minneapolis.

Finegold, S.M. and Martin, W.J. (1982): "Diagnostic Microbiology." 6th Ed., the C.V. Mosby Company, London.

Helm, R. A.; Porwollik, S.; Stanley, A. E,; Maloy, S.; McClelland, M.; Rabsch, W. and Eisenstark, A. (2004): Pigeon-associated strains of $\mathrm{S}$. enterica serovar Typhimurium phage type DT2 have genomic rearrangements at rRNA operons. Infect. Immun. 72(12): 7338-7341.

Homma, J.Y. (1982): "Designation of thirteen O-group antigens of $\mathrm{P}$. aeruginosa. An amendment for the tentative proposal in 1976." Jpn. J. Exp. Med., 52: 317-319.

Jeffrey, J. S.; Atwill, E. R. and Hunter, A. (2001) : Prevalence of Campylobacter and Salmonella at a squab (young pigeon) processing plant. Poult. Sci., 80(2):151155.

Kauffmann, F. (1973): "Serological diagnosis of Salmonella species." Kauffmann White Scheme, Copenhagen, Denmark.

Kimpe, A.; Decostere, A.; Martel, A.; Haesebrouck, F.and Devriese, L. A. (2002): Prevalence of antimicrobial resistance among pigeon isolates of Streptococcus gallolyticus, E. coli and S. enterica serotype Typhimurium. Avian Pathol., 31(4):393-397.

Koneman, E.W.; Allen, S.D.; Dowel, V.R. and Sommers, H.M. (1997): "Colour Atlas and Textbook of Diagnostic Microbiology." $2^{\text {nd }}$ Ed., Lippincott, Philadelphia, New York, London.

Lillehaug, A.; Monceyron, J. C.; Bergsjo, B.; Hofshagen, M.; Tharaldsen, J.; Nesse, L. L. and Handeland, K. (2005): Screening of feral pigeon (Colomba livia), mallard (Anas platyrhynchos) and graylag goose (Anser anser) populations for Campylobacter spp., Salmonella spp., avian influenza virus and avian paramyxovirus. Acta. Vet. Scand., 46(4):193-202.
Losito, P.; Vergara, A.; Muscariello, T. and Ianieri, A.(2005): Antimicrobial susceptibility of environmental S. aureus strains isolated from a pigeon slaughterhouse in Italy. Poult. Sci.,84(11):1802-1807.

McCrea, B.A.; Tonooka, K.H.; VanWorth, C.; Boggs, C.L. Atwill, E.R. and Schrader, J.S.( 2006): Prevalence of Campylobacter and Salmonella species on farm, after transport, and at processing in specialty market poultry. Poult. Sci., 85(1):136-143.

Methner, U. and Lauterbach, L. (2003): The detection of S. Typhimurium var. Copenhagen DT 2 in purebred pigeons Dtsch Tierarztl Wochenschr., 110 (6):239-244.

Pasmans, F.; Immerseel, F. V.; Hermans, K,; Heyndrickx, M.; Collard, J.; Ducatelle, R. and Haesebrouck, F. (2004): Assessment of virulence of pigeon isolates of $\mathrm{S}$. enterica subsp. enterica serovar Typhimurium var.Copenhagen for Humans J Clin. Microbiol., 42(5): 2000-2002.

Pedersen, K.; Clark, L.; Andelt, W. F. and Salman, M. D.( 2006): Prevalence of shiga toxin-producing E.coli and S. enterica in rock pigeons captured in Fort Collins, Colorado. J Wildl Dis., 42(1):46-55.

Pennycott, T. W.; Cinderey, R. N.; Park, A.; Mather, H. A.; Foster, G. and Grant, D. (2005): Further monitoring for Salmonella species and Escherichia coli O86 at a bird table in south-west Scotland. Vet. Rec., 15; 157(16):477480.

Quinn, P.J.; Carter, M.E.; Markey, B. k.; Donnelly, W.J.C. and Leonard, F.C. (2002): "Veterinary Microbiology and Microbial Disease." Great Britain by MPG, Book Ltd, Bodmin, Corn wall, U.K.

Robins-Brown, R.M.; Takeda, R.M. and Fasano, T. (1993): "Assessment of enterotoxin production by $Y$. enterocolitica and identification of a novel heat stable enterotoxin produced by a non invasive Y. enterocolitica strains isolated from clinical material." Infect. Immun., 61 (2): 746- 767.

Seepersadsingh, N. and Adesiyun, A .A. (2003): Prevalence and antimicrobial resistance of Salmonella spp. in pet mammals, reptiles, fish aquarium water, and birds in 
Trinidad. J Vet. Med. B. Infect. Dis. Vet. Public. Health., 50 (10): 488-493.

Soncini, G.; Valnegri, V.L.; Vercellotti, L.; Colombo, F.; Valle, D.; Franzoni, M. and Bersanii, C. (2006): Investigation of Campylobacter in reared game birds. $\mathrm{J}$ Food Prot., 69(12):3021-3024.

Sonntag, A.K.; Zenner, E.; Karch, H. and Bielaszewska, M. (2005): Pigeons as a possible reservoir of Shiga toxin 2f-producing E. coli pathogenic to humans. Berl Munch Tierarztl Wochenschr, 118(11-12): 464-470.
Tanaka, C.; Miyazawa, T.; Watarai, M. and Ishiguro, N. (2005): Bacteriological survey of faeces from feral pigeons in Japan. J Vet. Med. Sci., 67(9): 951-953.

Tomasz, A. (1994): Multiple-antibiotic-resistant pathogenic bacteria. New England Journal of Medicine 330: 1247-1251.

Williams, R. J., and Heymann, D. L. (1998): Containment of antibiotic resistance. Science 279: 11531154.

\section{در اسات بكتريولوجيه للميكروبات للمسببات المرضيه في الحمام المصري}

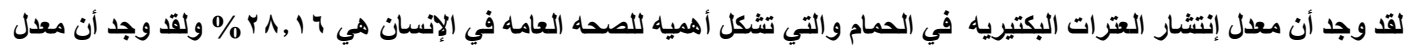

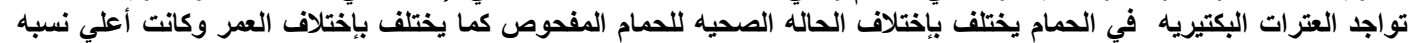



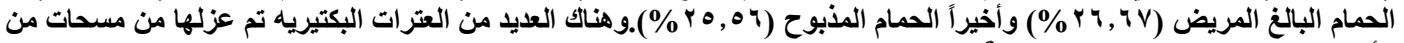
الأنف والثرج من الحام المريض شاملة العترات التاليه:( C. jejuni, Citrobacter freundii, D. pneumoniae, E. coli, K. oxytoca, K. pneumoniae, Mannheimia haemolytica, P. aeruginosa, Salmonella spp, S. aureus and Y. (enterocolitica.

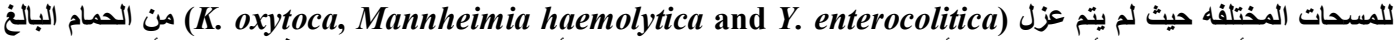

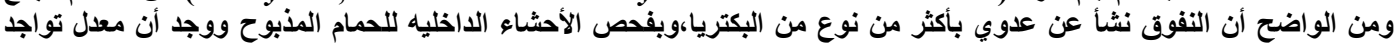

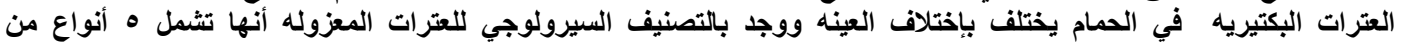

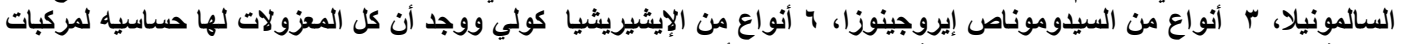



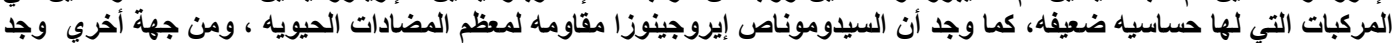

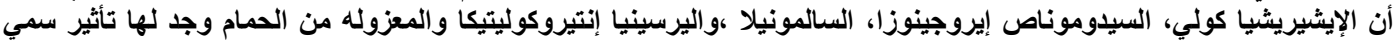

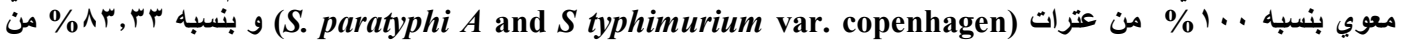

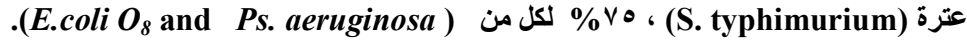


